\title{
RANCANG BANGUN TAS PUNGGUNG PINTAR UNTUK ANAK DENGAN LOAD CELL 5 KG, GPS DAN SMS BERBASIS ARDUINO MEGA 2560
}

\author{
Ahmad Baihaqi ${ }^{1}$, Wisnu Djatmiko ${ }^{2}$, Muhammad Yusro $^{3}$ \\ ${ }^{1}$ Mahasiswa Prodi Pendidikan Teknik Elektronika, Fakultas Teknik - UNJ \\ ${ }^{2}$ Dosen Prodi Pendidikan Teknik Elektronika, Fakultas Teknik - UNJ \\ ${ }^{3}$ Dosen Prodi Pendidikan Teknik Elektronika, Fakultas Teknik - UNJ
}

\begin{abstract}
Abstrak Bertujuan untuk Tujuan Penelitian ini adalah membuat sistem Tas Punggung yang dapat memantau berat tas punggung yang digunakan anak, memantau posisi GPS yang terdapat pada tas punggung, dan menginformasikan berat dan posisi tas punggung melalui komunikasi SMS. Hasil Penelitian Tas Punggung Pintar dapat direalisasikan dengan penggabungan sub-sistem yang berfungsi dengan baik, diantaranya : Arduino Mega 2560, Modul Buck Converter Adjustable IC LM2956, Sistem Display berbasis LCD \& Keypad dan I2C, Sistem Pengukur Berat Bebasis Load Cell 5Kg-TAL220B dan ADC 24-bit HX711, Modul GPS Neo 6M-V2, Buzzer, RTC, Modul SIM 800L, dan Baterai Li-Po 3 sel. Sistem Tas Punggung Pintar dapat memberikan informasi berat isi tas dengan keakuratan pengukuran dengan akuratan mencapai $\pm 0,3 \mathrm{Kg}$, dapat memberikan informasi posisi GPS dengan tingkat rata-rata keakuratan mencapai 31,72 meter, dan dapat memberikan informasi kepada smartphone pengguna berat isi tas dan posisi GPS0 memalui komunikasi SMS dengan baik dengan daya tahan baterai mencapai 8 jam sebelum diisi ulang.
\end{abstract}

Kata kunci: Tas punggung, load cell, GPS, SMS, Li-Po, Arduino

\section{Pendahuluan}

Menurut Legiran (2012) penelitian yang dilakukan pada siswa sekolah dasar (SD) kelas IV-VI, tas punggung merupakan tas yang paling dominan digunakan untuk kegitan sekolah. Membawa tas telah diketahui berhubungan dengan keluhan muskuloskeletal daerah punggung yang dapat terjadi jika berat tas yang dibawa melebihi batas $10 \%$ dari berat tubuh. Prevalensi nyeri dijumpai pada 131 siswa (41,3\%) dan tidak nyeri 186 siswa $(58,7 \%)$. Keluhan nyeri dikelompokkan menjadi nyeri spinal (leher, punggung atas, pinggang) dan non spinal (bahu, siku, pergelangan tangan, tangan). Anak rentan menjadi objek tindakan kriminal. Salah satu kasus yang meresahkan masyarakat adalah kasus anak hilang. Sepanjang tahun 2011 hingga 2016, Komisi Perlindungan Anak Indonesia 
(KPAI) mencatat kasus anak hilang menyentuh angka 233 kasus (KPAI, 2016). Grafik rincian kasus anak hilang dapat dilihat pada Gambar 1.

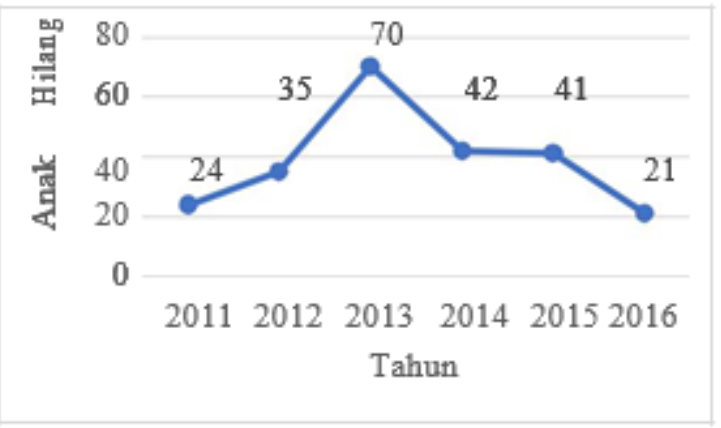

Gambar 1.1 Grafik Rincian Kasus Anak Hilang

Untuk mengatasi masalah-masalah diatas, perlu adanya sebuah sistem pengukur berat tas anak dan pemantau posisi anak. Pengukur berat tas anak yang dapat mengukur berat tas anak agar tidak melebihi berat tas yang direkomendasikan ahli. Pemantau posisi anak yang dapat memberikan informasi kepada orang tuanya dimana posisi anak berada.

\section{Metode}

Penelitian Tas Punggung Pintar secara khusus menggunakan model R\&D yang dikembangkan oleh Brog \& Gall. Menurut Silalahi (2017: 10) prinsip dasar yang merupakan karakteristik metode R\&D 4 Tahap Model Borg Gall, yaitu: (1) tahap analisis, (2) tahap perancangan, (3) tahap pengembangan, (4) tahap pengujian.[7] Langkah-langkah penelitian dapat dilihat pada Gambar 2.1

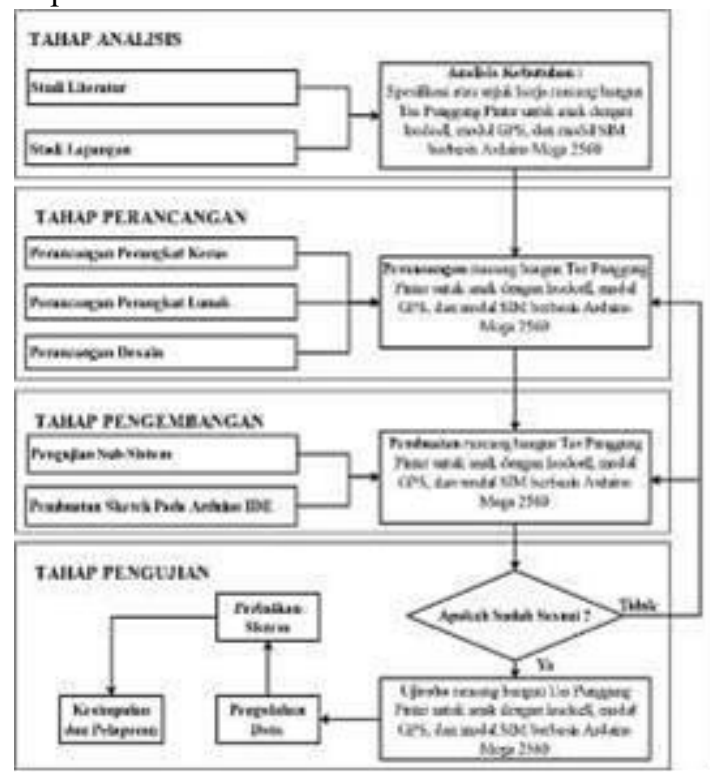

Gambar 2.1 Langkah - langkah penelitian Tas Punggung Pintar dengan model Brog \& Gall Diagram blok sistem Tas Punggung Pintar dapat dilihat pada Gambar 2.2 


\section{Hasil}

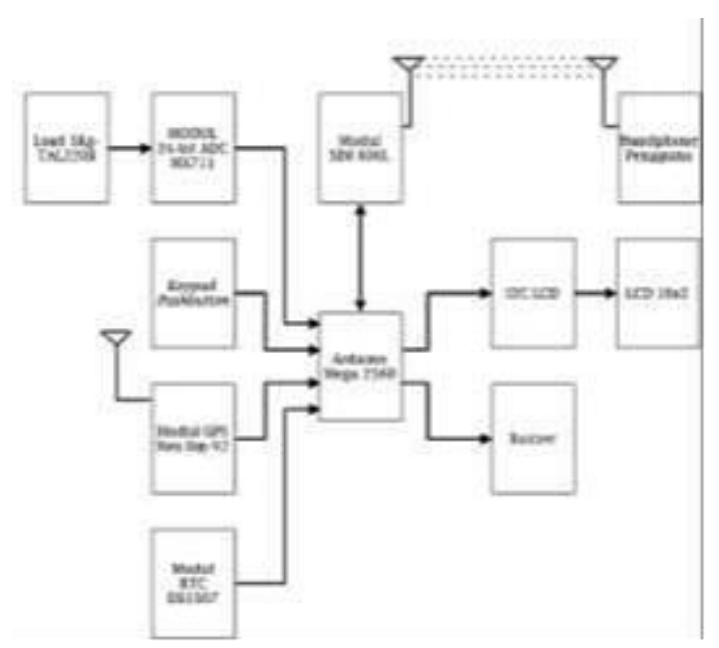

Gambar 2.2 Diagram Blok Sistem Tas Punggung Pintar

\section{1 analisis data penelitian}

Berat Tas Punggung Pintar disaat kosong adalah 1,5 Kg. Pada bagian luar Tas Punggung Pintar memiliki dimensi $15 \times 30 \times 45 \mathrm{~cm}$ dan terdapat tombol power, input pushbutton (select, right, left, up, and down) dan beberapa indikator, diantaranya : indikator power (led hijau), tampilan LCD 16x2, indikator sinyal SIM800L (led merah), indikator sinyal GPS (led putih) dan indikator alaram. Desain Tas Punggung Pintar bagian luar dapat dilihat pada Gambar 3.1

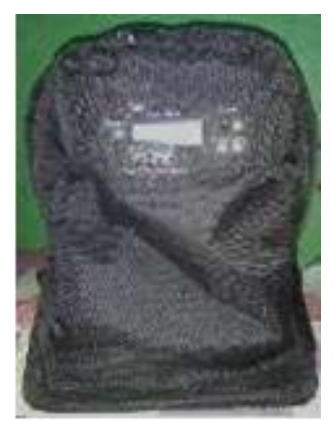

Gambar 3.1 Desain Rancangan Tas Punggung Pintar Tampak Depan

Bagian dalam tas memiliki dua bagian yakni main box dan control box. Bagian main box yang akan di isi barang bwaan yang memiliki dimensi $13 \times 25 \times 30 \mathrm{~cm}$, sedangkan control box berisi komponen sistem Tas Punggung Pintar. Desain Tas Punggung Pintar bagian dalam dapat dilihat pada Gambar 3.2 


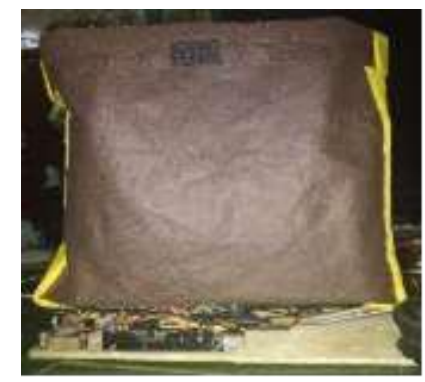

Gambar 3.2 Desain Rancangan Tas Punggung Pintar Bagian Dalam

Hasil Pengujian Sistem Display Berbasis LCD \& Keypad Hasil pengujian sistem display berbasis LCD \& Keypad dapat dilihat pada Tabel 3.1

TABEL 3.1 HASIL PENGUJIAN SISTEM DISPLAY BERBASIS LCD \& KEYPAD

\begin{tabular}{|c|c|c|c|}
\hline No & $\begin{array}{l}\text { Penatab Sketch Anduine } \\
\text { IDE }\end{array}$ & $\begin{array}{c}\text { Tampilas LCD } \\
16 \times 02\end{array}$ & Hasil \\
\hline t. & $\begin{array}{c}\text { ABCDEFGHUKL.MNO } \\
\text { PQRSTUVWXYZ }\end{array}$ & $\begin{array}{l}\text { ABCDEFGHIKI MNO } \\
\text { PORSTUVWXYZ }\end{array}$ & OK \\
\hline 2. & $\begin{array}{l}\text { Abcidefiglajelinno } \\
\text { Postavwxyz }\end{array}$ & $\begin{array}{l}\text { Abedefglijulmano } \\
\text { Pogntovwxyz. }\end{array}$ & Ok \\
\hline 3. & $\begin{array}{l}0123456789 \\
\pm 1, \ldots+\ldots\end{array}$ & $\begin{array}{l}\text { 0i234567k9 } \\
1 !, \ldots+\ldots 10\end{array}$ & ok \\
\hline
\end{tabular}

Pengujian Sistem Display Berbasis LCD \& Keypad Hasil pengujian pertama load cell $5 \mathrm{Kg}$ TAL220B didapatkan dari membandingkan hasil pengukuran menggunakan load cell $5 \mathrm{Kg}$ TAL220B dengan timbangan digital B05 $5 \mathrm{Kg}$. Tabel hasil pengujian pertama load cell 5Kg-TAL220B dapat dilihat pada Tabel 3.2

TABEL 3.2 HASIL PENGUJIAN PERTAMA LOAD CELL 5KG-TAL220B DENGAN

\begin{tabular}{|c|c|c|c|c|}
\hline No. & $\begin{array}{l}\text { Timbangan } \\
\text { Timbangas Dapur } \\
\text { Digital Bo5 } 5 \mathrm{Kg}\end{array}$ & $\begin{array}{l}\text { Losd Cell } 5 \mathrm{Kg}^{-} \\
\text {TAt.220B }\left(\mathrm{Kg}_{\mathrm{g}}\right)\end{array}$ & Selìsih & Hasi \\
\hline 1. & 0,1 & 0,1 & 0 & Ok \\
\hline 2. & 0,5 & 0.5 & 0 & ok \\
\hline 3. & 1 & 1 & 0 & ox \\
\hline 4 & 2 & 15 & 0 & Ok \\
\hline 5 & 3 & 3.0 & 0 & $\mathrm{OK}$ \\
\hline 6. & 4.5 & 4,5 & 0 & Ok \\
\hline 7. & 5 & 5.0 & 0 & ok \\
\hline
\end{tabular}

Pengujian Sistem Display Berbasis LCD \& Keypad Pengujian modul GPS Neo 6M-V2 dilakukan dengan cara membandingkan dengan GPS smartphone kemudian diukur selisih jarak antara kedua titik dengan aplikasi pada smartphone Android yaitu Measure Maps V.1.67. Tabel hasil pengujian modul GPS Neo 6M-2 dapat dilihat pada Tabel 3.3

TABEL 3.3 HASIL PENGUJIAN MODUL GPS NEO 6M-V2 


\begin{tabular}{|c|c|c|c|c|c|c|c|}
\hline \multirow[t]{2}{*}{ No. } & \multirow[t]{2}{*}{ Lokmi } & \multicolumn{2}{|c|}{$\begin{array}{l}\text { Data Posial GPS } \\
\text { Snavitpioine }\end{array}$} & \multicolumn{2}{|c|}{$\begin{array}{l}\text { Das Posisi OrS } \\
\text { Modul Girs } \\
\text { Neo QALV2 }\end{array}$} & \multirow{2}{*}{$\begin{array}{l}\text { Selisith } \\
\text { fanak } \\
\text { Poois } \\
\text { GPs } \\
\text { (a) }\end{array}$} & \multirow[t]{2}{*}{ Hasil } \\
\hline & & Loeg & Lat & Lene & Lat & & \\
\hline t. & $\begin{array}{l}\text { Heaman } \\
\text { Pustikoms } \\
\text { UNJ }\end{array}$ & -6.19424 & 106.87895 & -6.1903 & 106.57916 & 19,08 & ot \\
\hline 2. & Tugs UNS & -6.18519 & 10687826 & -619531 & 106.59841 & 21.39 & ok \\
\hline 3. & $\begin{array}{l}\text { Depaa } \\
\text { BWKK } \\
\text { UNI }\end{array}$ & -6.59885 & 10687819 & -4.19600 & เo6.xางด & 23,55 & ok \\
\hline 4. & $\begin{array}{l}\text { Paaggung } \\
\text { I ikosomi } \\
\text { UNJ } \\
\text { Telaik }\end{array}$ & -6.19367 & 106.8778 & -1.19378 & 106.87761 & 11,01 & Ok \\
\hline s. & $\begin{array}{l}\text { Dekktro } \\
\text { UNI }\end{array}$ & -6.19361 & 10657844 & -6.19374 & 106.57851 & Isss & ok \\
\hline & \multicolumn{5}{|c|}{ Rata-Ruta Seliaih Nerk Posidi GPS } & 1789 & \\
\hline
\end{tabular}

Hasil Pengujian Modul SIM800L Pengujian SIM800L dilakukan dengan cara mengirim data berat tas dan data posisi GPS melalui komunikasi SMS. Tabel hasil pengujian modul SIM 800L dapat dilihat pada Tabel 3.4

TABEL 3.4 HASIL PENGUJIAN MODUL SIM800L

\begin{tabular}{|c|c|c|c|c|c|}
\hline $\mathrm{Na}$ & $\begin{array}{c}\text { SMES } \\
\text { Masile Ke } \\
\text { Modut } \\
\text { SIM soe. }\end{array}$ & $\begin{array}{l}\text { Neman } \\
\text { Pengirn }\end{array}$ & 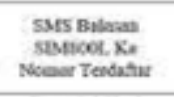 & $\begin{array}{l}\text { SMS belmax yrag } \\
\text { dilerima toovout } \\
\text { Terdafias }\end{array}$ & Hosil \\
\hline L. & คมHLT & Tenturat & 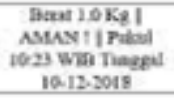 & 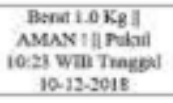 & Dk \\
\hline 2. & GPs? & Toulatie & 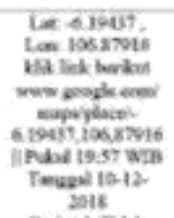 & 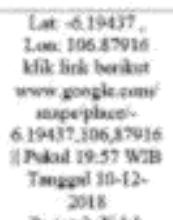 & es: \\
\hline 3. & bay & Tontuliur & 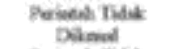 & 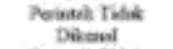 & $\bar{a}$ \\
\hline 2. & eps: & Toulieser & $\begin{array}{l}\text { Persendit That: } \\
\text { Dicend }\end{array}$ & $\begin{array}{l}\text { Fouibih Toblat } \\
\text { Dikenal }\end{array}$ & ce \\
\hline 5 & $\begin{array}{l}\text { Holle: } \\
\text { stussed: }\end{array}$ & Tentubur & $\begin{array}{c}\text { Poineib That } \\
\text { Divase }\end{array}$ & 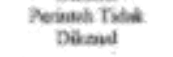 & a \\
\hline 6 & Burat & Thus & 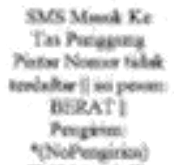 & 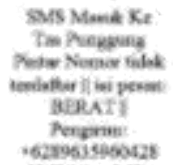 & Ca. \\
\hline 7 & che & $\begin{array}{l}\text { Tous: } \\
\text { Tendafie }\end{array}$ & 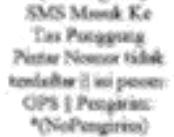 & 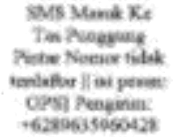 & cs \\
\hline a. & $\begin{array}{l}\text { Pulla: } \\
\text { sexpeot. }\end{array}$ & Thaid & 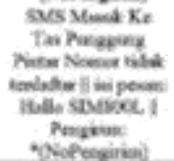 & 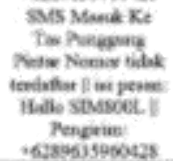 & 64 \\
\hline
\end{tabular}

Hasil Pengujian Baterai Tanpa Beban Tabel hasil pengujian sumber tegangan baterai Li-Po 3 sel tanpa beban dapat dilihat pada Tabel 3.5

TABEL 3.5 HASIL PENGUJIAN SUMBER TEGANGAN BATERAI LI-PO SEL TANPA BEBAN 


\begin{tabular}{|c|c|c|c|}
\hline No & Parameter & Koodisa & Teganga (V) \\
\hline 1 & $\begin{array}{l}\text { Buterai Li-Po } 3 \text { Ses Ochos } \\
1200 \mathrm{~m} \mathrm{Al}\end{array}$ & $\begin{array}{l}\text { Buterai Terini } \\
\text { Peach }\end{array}$ & 126 \\
\hline
\end{tabular}

Hasil Pengujian Baterai Li-Po 3s 1400mAh dengan Beban Sistem Tas Punggung Pintar. Tabel hasil pengujian sumber tegangan baterai Li-Po 3 sel dengan beban sistem Tas Punggung Pintar dapat dilihat pada Tabel 3.6

TABEL 3.6 HASIL PENGUJIAN SUMBER TEGANGAN BATERAI LI-PO SEL DENGAN BEBAN SISTEM TAS PUNGGUNG PINTAR.

\begin{tabular}{|c|c|c|c|c|c|}
\hline No & Parameter & Koetolss Buterci & $\begin{array}{l}\text { Koudisi } \\
\text { Sogtem }\end{array}$ & $\begin{array}{c}\text { Tegengen } \\
(\mathrm{V})\end{array}$ & Aars \\
\hline 1. & $\begin{array}{l}\text { Baterai Li. Po } \\
\text { 3. Sel Onbo } \\
\text { I400m }\end{array}$ & $\begin{array}{c}\text { Matarni Tenai } \\
\text { Fesuh }\end{array}$ & $\begin{array}{c}\text { Stant } \\
\text { All Da }\end{array}$ & $8.3 \mathrm{~V}$ & $170 \mathrm{~mA}$ \\
\hline 2. & $\begin{array}{l}\text { Baterai LifFo } \\
3 \text { Set Oobo } \\
\text { 14EStinat }\end{array}$ & $\begin{array}{c}\text { Hatecri Tensi } \\
\text { Peanith }\end{array}$ & Stanty & $3.3 \mathrm{~V}$ & $155 \mathrm{ma}$ \\
\hline 3. & $\begin{array}{l}\text { Baterai Li.Po } \\
3 \text { Sel Ooto } \\
\text { IAeermAh }\end{array}$ & $\begin{array}{c}\text { Pryersi Tesad } \\
\text { Pvesel }\end{array}$ & $\begin{array}{l}\text { Rend and } \\
\text { Send GPS } \\
\text { med } 5 \mathrm{MS}\end{array}$ & $8.3 \mathrm{~V}$ & $160 \mathrm{~mA}$ \\
\hline
\end{tabular}

Dari tabel diatas penggunaan arus paling besar adalah saat kondisi sistem start all on dengan penggunaan $170 \mathrm{~mA}$ dengan kapasitas baterai Li-Po $3 \mathrm{~S} 1400 \mathrm{mAH}$, maka untuk menentukan waktu pemakain baterai dengan rumusan berikut :

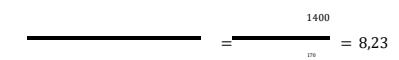

Hasil Pengujian Daya Tahan Baterai Sebelum Diisi Ulang Tabel hasil pengujian daya tahan baterai sebelum diisi ulang dapat dilihat pada Tabel 3.7

TABEL 3.7 HASIL PENGUJIAN DAYA TAHAN BATERAI SEBELUM DIISI ULANG

\begin{tabular}{|c|c|c|}
\hline No & $\begin{array}{c}\text { Waktu Pemakaian } \\
\text { Setelah }\end{array}$ & Kondisi Sistera Tas Punggung Pintar \\
\hline 1. & 2Jam & Sistem Normal \\
\hline 2. & $4 \mathrm{Jan}$ & Sistem Nemal \\
\hline 3. & $6 \operatorname{Ian}$ & Sistem Normal \\
\hline 4. & 8 Jam & $\begin{array}{l}\text { LCD meredup tidak menampitikan kata } \\
\text { Komanilcati SMS masih dupat } \\
\text { dilakokan untuk madepatkan data } \\
\text { berat dant posisi }\end{array}$ \\
\hline s. & $8 \operatorname{Jam} 45$ menit & Sistem Mati \\
\hline
\end{tabular}

Hasil Pengujian Lama Waktu Pengisian Baterai Li-Po 3 sel 1400mAh Tabel Hasil Pengujian Lama Waktu Pengisian Baterai Li-Po 3 sel 1400mAhdapat dilihat pada Tabel 3.8

TABEL 3.8 HASIL PENGUJIAN LAMA WAKTU PENGISIAN BATERAI LI-PO 3 SEL 1400MAH

\begin{tabular}{ccc}
\hline No & Parameter & Lama Waktu Pengisian \\
\hline 1 & $\begin{array}{c}\text { Baterai Li-Po } 3 \text { Sel } \\
\text { Onbo } 1400 \mathrm{mAh}\end{array}$ & 120 Menit (2 jam) \\
\hline
\end{tabular}

Hasil Pengujian Sistem Tas Punggung Pintar Pengujian sistem Tas Punggung Pintar dilakukan dnegan cara menggabungkan sub-sistem menjadi satu kesatuan yang menghasilkan tabel hasil pengujian sistem Tas Punggung Pintar yang dapat dilihat pada Tabel 3.9 
TABEL 3.9 HASIL PENGUJIAN LAMA WAKTU PENGISIAN BATERAI LI-PO 3 SEL 1400MAH

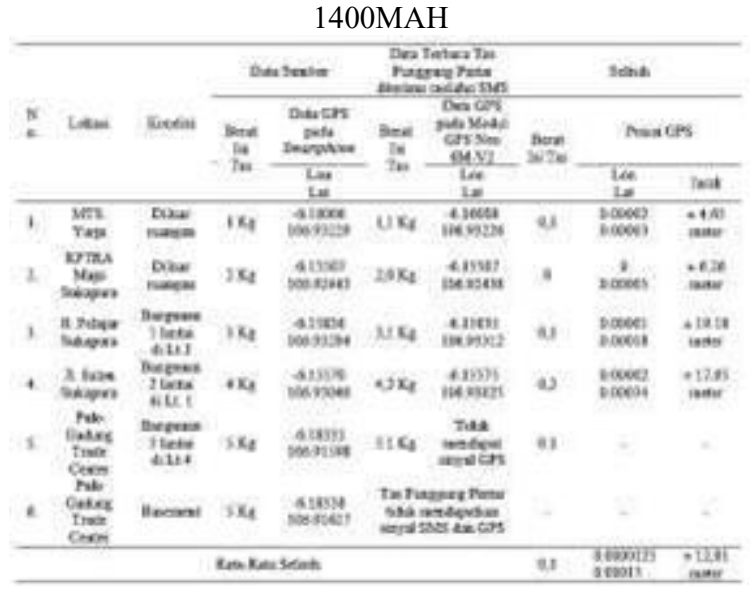

\subsection{Pembahasan}

Pengujian Sistem Tas Punggung Pintar dilakukan dengan cara menguji satu per satu sub-sistem yang akan digunakan yang terdiri dari sistem display berbasis LCD \& Keypad dan I2C, sistem pengukur berat berbasis load cell TAL-220 dan ADC HX7111, modul GPS Neo 6M-V2, Modul SIM 8001, sumber tegangan baterai Li-Po, dan Arduino Mega 2560. Pada Tabel IV. dilakukan pengujian pada sistem display berbasis LCD \& Keypad dan I2C menghasilkan tampilan LCD 16x2 yang sesuai dengan perintah yang dibuat. Hal ini membuktikan bahwa sistem display berbasis LCD \& Keypad dan I2C dalam kondisi baik. Pada Tabel V. dilakukan pengujian pada sistem pengukur berat berbasis load cell TAL220B dan ADC HX711 menghasilkan pengkuran berat yang akurat dengan tingkat keakuratan mencapai $100 \%$. Hal ini membuktikan bahwa sistem pengukur berat berbasis load cell TAL-220B dan ADC HX711 dalam kondisi baik. Pada Tabel VI. dilakukan pengujian pada modul GPS Neo 6M-V2 menghasilkan posisi GPS yang cukup akurat dengan tingkat rata-rata keakuratan mencapai 17,89 meter dari 5 kali percobaan dari tempat berbeda. Hal ini membuktikan bahwa modul GPS Neo 6M-V2 dalam kondisi baik. Pada Tabel VII. dilakukan pengujian pada modul SIM 800L menghasilkan ketika modul SIM 800L menerima SMS maka akan mengirimkan SMS balasan yang sesuai dengan perintah yang ditulis dalan sketch program. Hal ini membuktikan bahwa modul GPS Neo 6M-V2 dalam kondisi baik. Pada Tabel VIII. dan Tabel IX. dilakukan pengujian tegangan pada sumber tegangan baterai Li-Po 3 sel Onbo1400mAh. Pengujian dilakukan disaat baterai LiPo 3 sel tanpa beban dalam kondisi terisi penuh baterai mengeluarkan tegangan sebesar 12,6 VDC dan pengujian dilakukan disaat baterai Li-Po 3 sel dengan beban secara keseluruhan sistem Tas Punggung Pintar didapatkan bahwa penggunaan arus paling besar adalah saat kondisi sistem start all on dengan arus $170 \mathrm{~mA}$ dengan kapasitas baterai Li-Po 3S 1400mAH, maka dengan penghitungan didapatkan untuk menentukan waktu pemakaian 8 jam 15 menit. Pada Tabel X. dilakukan pengamatan daya tahan baterai Li-Po secara langsung didapatkan bahwa sistem Tas Puggung Pintar dapat berjalan dengan normal pada 8 jam pemakaian. Setelah 8 jam Pemakaian LCD meredup tidak menampilkan kata namun komunikasi SMS masih dapat dilakukan untuk mndapatkan data berat isi tas dan posisi GPS. Setelah 8 jam 45 mnit pemakaian maka sistem mati total dan butuh diisi ulang. Pada Tabel XI. dilakukan pengisian ulang baterai Li-Po 3 sel Onbo 1400 mAh dengan charger khusus untuk baterai Li-Po. Setelah melakukan pengisian selama 2 jam buzzer pada charger khusus untuk baterai Li-Po berbunyi yang menandakan baterai Li-Po 3 sel Onbo $1400 \mathrm{mAh}$ telah terisi penuh. Pada Tabel XII. dilakukan pengujian sistem Tas Punggung Pintar yang 
didapatkan bahwa Setelah sub-sistem dirangkai menjadi sbuah sistem Tas Punggung Pintar dapat mengukur berat isi tas dengan ketepatan pembacaan hingga $\pm 0,3 \mathrm{Kg}$, keakutan GPS mencapai \pm 25 meter, dan komunikasi SMS dapat dengan baik saat sistem berada diluar ruangan, dibangunan berlantai 1 dan bangunan berlantai 2 . Saat sistem berada pada bangunan belantai lebih dari 2, komunikasi SMS masih dapat dilakukan dengan sistem, akantetapi sistem tidak mendapatkan sinyal GPS. Sedangkan saat berada di basement sistem tidak dapat melakukan komunikasi SMS maupun mengakses data GPS. Berdasarkan hasil pengujian pada seluruh sub-sistem dan sistem secara keseluruhan yang sudah dilakukan, diketahui bahwa keriteria yang pengujian pada masing-masing sub-sistem dan sistm secara keseluruhan telah tercapai dan berjalan dengan baik.

\subsection{Aplikasi Hasil Penelitian}

Berdasarkan peranacangan dan hasil pengujian yang sudah dilakukan maka Tas Punggung Pintar dapat diaplikasikan untuk memantau berat Tas Punggung Pintar yang digunakan anak, memantau posisi GPS yang terdapat pada Tas Punggung Pintar, dan menginformasikan berat dan posisi Tas Punggung Pintar melalui komunikasi SMS.

\section{Kesimpulan}

Berdasarkan hasil penelitian Tas Punggung Pintar yang sudah dilakukan dapat disimpulkan bahwa:1.Sistem Tas Punggung Pintar dapat direalisasikan dengan penggabungan subsistem yang berfungsi dengan baik, diantaranya : Arduino Mega 2560, Modul Buck Converter Adjustable IC LM2956, Sistem Display berbasis LCD \& Keypad dan I2C, Sistem Pengukur Berat Bebasis Load Cell 5Kg-TAL220B dan ADC 24-bit HX711, Modul GPS Neo 6M-V2, Buzzer, RTC, Modul SIM 800L, dan Baterai Li-Po 3 sel. Sistem Tas Punggung Pintar dapat mengukur berat isi tas hingga $5 \mathrm{Kg}$ dengan keakuratan pengukuran yang mencapai $\pm 0,3 \mathrm{Kg}$. Sistem Tas Punggung Pintar dapat membaca posisi GPS longitude dan latitude dengan keakuratan pembacaan posisi GPS dengan tingkat mencapai \pm 25 meter. Sistem Tas Punggung Pintar dapat memberikan informasi kepada smartphone pengguna berat isi tas dan posisi GPS dengan baik dilakukan saat sistem berada diluar ruangan, dibangunan berlantai 1 dan bangunan berlantai 2. Saat sistem berada pada bangunan belantai lebih dari 2, komunikasi SMS masih dapat dilakukan dengan sistem, akantetapi sistem tidak mendapatkan sinyal GPS. Sedangkan saat berada di basement sistem tidak dapat melakukan komunikasi SMS maupun mengakses data GPS. Sistem Tas Punggung Pintar mampu bertahan dengan waktu pemakaian \pm 8 jam setelah melakukan penghitungan dan pengujian

\section{DATAR PUSTAKA}

1. Syahwil, M. (2013). Panduan Mudah Simulasi dan Praktik Mikrokontroler Arduino. Yogyakarta: CV. Adi Offset.

2. Phulphagar, V., \& Jaiswal, R. (2017). Arduino Controlled Weight Monitoring With Dashboard Analysis. International Journal for Research Applied Sience \& Tecnology, 5(11):1164-1167.Nauly, M. P., (2015). Detektor Posisi Kendaran Bermotor dengan Sensor GPS dan Aplikasi Android (Transmitter) [Tugas Akhir]. Palembang : Teknik Elektro, Politeknik Negeri Swiwijaya Palembang.

3. Alshamsi, H., Këpuska, V., \& Alshamsi, H. (2016). Real Time Vehicle Tracking Using Arduino Mega. International Journal of Science and Technology, 5(12):624-627.

4. Peryoga, L. W., Retnowati, I., \& Siswoyo, I. B. (2006). Pengendalian Suhu Kelembaban Ruang Ekstraksi Metode Maserasi Minyak Atsiri Melati Kontroler PID Berbasis Arduino Mega. Jurnal Universitas Brawijaya : Penelitian Laksana Widya Prayoga,. 1-6. 
5. Widodo, Y. J. H., (2017). Charger Baterai Li-Po 3 Sel Menggunakan Flyback Konverter Dengan Masukan 220 VAC Input [Tugas Akhir]. Yogyakarta : Fakultas Sains dan Teknologi, Universitas Sanata Dharma.

6. Silalahi, A. 2017. Development Research (Penelitian Pengembangan) dan Research \& Development (Penelitian \& Pengembangan) Dalam Bidang Pendidikan/Pembelajaran. [Prosiding] Seminar \& Workshop Penelitian Disertasi Program Doktoral Pascasarjana Universitas Negeri Medan. Sumatra Utara, 3-4 Feb 2017. Hlm. 1-13.

7. Baihaqi, A., (2019). Rancang Bangun Tas Punggung Pintar Untuk Anak Dengan Load Cell 5Kg, GPS, dan SMS Berbasis Arduino Mega 2560. 